\title{
Bioavailability of Metals at a Southeastern Brazilian Coastal Area of High Environmental Concern Under Anthropic Influence: Evaluation Using Transplanted Bivalves (Nodipecten nodosus) and the DGT Technique
}

\author{
Monizze Vannuci-Silva • João M. de Souza • Fábio Francisco de Oliveira • \\ Marcus A. G. de Araújo Jr • Eleine Francioni - Carlos Eduardo Eismann • \\ Chang H. Kiang • José S. Govone • Maria J. Belzunce-Segarra • \\ Amauri Antonio Menegário
}

Received: 3 January 2017 / Accepted: 2 May 2017 / Published online: 29 May 2017

(C) Springer International Publishing Switzerland 2017

\begin{abstract}
Metals are commonly determined in aquatic organisms, primarily using bivalves to provide important data on their bioavailability. The technique of diffusive gradients in thin films (DGTs) has also been employed to assess the concentration of metals in freshwater and marine environments, determining their
\end{abstract}

M. Vannuci-Silva • C. E. Eismann - C. H. Kiang •

J. S. Govone · A. A. Menegário $(\square)$

São Paulo State University (Unesp), Environmental Studies

Center, Rio Claro, SP 13506-900, Brazil

e-mail: amenega@rc.unesp

J. M. de Souza · M. A. G. de Araújo Jr, · E. Francioni PETROBRAS/CENPES/Gerência de Avaliação e Monitoramento Ambiental, Rio de Janeiro, RJ, Brazil

F. F. de Oliveira

Pontifícia Universidade Católica do Rio de Janeiro, Rio de Janeiro, RJ, Brazil

C. H. Kiang · J. S. Govone

Universidade Estadual Paulista, Instituto de Geociências e

Ciências Exatas (IGCE), Rio Claro, SP, Brazil

M. J. Belzunce-Segarra

AZTI Tecnalia, Marine Research Division, 20110 Pasaia, Spain

Present Address:

M. Vannuci-Silva

Department of Animal Biology, Institute of Biology, University of Campinas - UNICAMP, P.O. Box: 6109, Campinas 13083-970

SP, Brazil lability. The present work evaluated and compared the labile and bioavailable concentrations of $\mathrm{Cd}, \mathrm{Co}, \mathrm{Cu}$, $\mathrm{Mn}, \mathrm{Ni}$ and $\mathrm{Pb}$ in seawater from Ilha Grande Bay, $\mathrm{RJ}$, using DGT and transplanted bivalves (Nodipecten nodosus), respectively. The scallops and DGTs were immersed in water at three sampling locations within the bay from July to September 2012 (winter campaign) and from December 2012 to February 2013 (summer campaign). The metals were determined by inductively coupled plasma-mass spectrometry (ICP-MS) and optical emission spectrometry (ICP-OES). DGT technique was successfully used to determine the concentrations of metals in waters, except for $\mathrm{Pb}$ when short deployment times were used. All metals were determined using transplanted bivalves ( $N$. nodosus), but pre-exposure to $\mathrm{Cd}$ was evident, which made the interpretation of the data for this analyte difficult. The data on metal lability in Ilha Grande Bay waters obtained from the DGT technique were correlated with the metal bioavailability determined in the soft tissues of the transplanted $N$. nodosus for $\mathrm{Co}, \mathrm{Cu}, \mathrm{Mn}, \mathrm{Ni}$ and $\mathrm{Pb}$. This is the first evaluation of this type for this area of high environmental concern. Both techniques revealed that Náutico was the location with the highest concentration of metals in the study area.

Keywords Bioaccumulation · Bioavailability Bivalves $\cdot$ Labile $\cdot$ Metals $\cdot$ Passive sampler 


\section{Introduction}

Ilha Grande Bay (IGB) is located in the south of the Rio de Janeiro state and covers an area of $1.124 \mathrm{~km}^{2}$ with a $350-\mathrm{km}$ perimeter by the water line. For its landscape beauty and floral and faunal richness, IGB has 11 conservation units, representing the highest number of units in the Rio de Janeiro state (Creed et al. 2007). Despite its ecological and environmental significance, IGB is threatened by many potential pollution and contamination sources. Local seawater frequently receives domestic and industrial sewage and waste from the cities of Angra dos Reis and Paraty. Additionally, there is intense tourist and leisure vessel traffic and a heavy presence of large ships (cruisers, cargos and tankers), as well as several harbours and marine terminals (Belo et al. 2002; Creed et al. 2007; Pinto 2008). Moreover, oil spills are a potential risk and have been reported in the area (Creed et al. 2007).

Anthropogenic activities may result in the discharge of many toxic substances, including metals, to aquatic systems, leading to higher concentrations than those found naturally in the environment. These high concentrations can reach organisms and enter into the food chain, damaging many life forms (Salomons et al. 1995; Salomons and Forstner 1984). As regards metals, they are present in different forms in the aquatic systems (e.g. free, complexed with ligands) that will determine their final fate in the environment. Thus, it is important to determine not only their total concentration but also the fraction potentially bioavailable to organisms. In this sense, bivalves have been widely used to monitor metals in the aquatic environment, providing data on the environmental bioavailable concentration of those contaminants (Galvão et al. 2009). Moreover, they have the ability to preconcentrate metals and can therefore be used to evaluate the presence of very low concentrations in the aquatic environment (Webb and Keough 2002). Among them, scallops, Nodipecten nodosus (Linnaeus, 1758), are the largest bivalve of the Pectinidae family occurring in Brazil. Due to its high commercial value and excellent market receptivity, this species has a great potential in shellfish farming (Fonseca 2004). Despite its importance, there are very few data on the bioaccumulation of metals in these organisms. Galvão et al. (2010) evaluated the cadmium bioaccumulation in some organs of $N$. nodosus from IGB, showing high bioaccumulation in the digestive glands.

Another approach is to use the diffusion gradient in thin film (DGT) devices to measure labile metal concentrations in aquatic systems. DGTs preconcentrate metals during the deployment time, providing timeintegrated metal concentrations. Several studies have compared the metal concentrations measured by DGTs and different organisms: bivalves (Amato et al. 2015; Clarisse et al. 2012; Schintu et al. 2008; Webb and Keough 2002), microcrustaceans (Tusseau-Vuillemin et al. 2004), amphipods (Stark et al. 2006) and algae (Bourgeault et al. 2013; Diviš et al. 2012; Ferreira et al. 2013; Ohlander et al. 2012; Schintu et al. 2010). Although a considerable number of studies have compared the DGT technique with biomonitoring, there are several conflicting conclusions. Thus, more studies with different species and in areas of high environmental concern are needed to obtain new data and gain a better understanding of the bioavailability of metals. The work presented here evaluated the labile and bioavailable concentrations of $\mathrm{Cd}, \mathrm{Co}, \mathrm{Cu}, \mathrm{Mn}, \mathrm{Ni}$ and $\mathrm{Pb}$ in seawater from IGB, RJ, using DGTs and transplanted bivalves (N. nodosus). Additionally, we compared the data obtained from both techniques to observe the similarities, discrepancies or complementarity of the determined availability of these metals in an area of high environmental concern.

\section{Experimental}

\subsection{Study Area and Field Campaigns}

Experiments were carried out at three sites inside IGB, Angra dos Reis, RJ. The sites were called Náutico (S

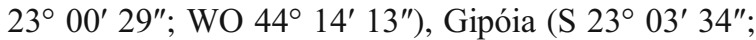

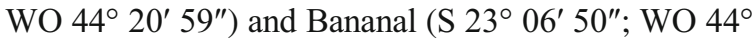
$15^{\prime} 50^{\prime \prime}$ ) (Fig. 1). Two sampling campaigns were performed: winter (July to September 2012) and summer (December 2012 to February 2013). The DGT devices and $N$. nodosus were immersed at the sampling sites in each campaign. An amount of samplers and bivalves (see Sects. 2.2.1. and 2.2.2., respectively) were collected for further analysis after 15, 30 and 60 days.

\subsection{Field Experiment}

\subsubsection{DGT Deployment}

Technique Principles The DGT technique is based on Fick's first law of diffusion (Davison and Zhang 1994; Zhang and Davison 1995). DGT devices accumulate the 


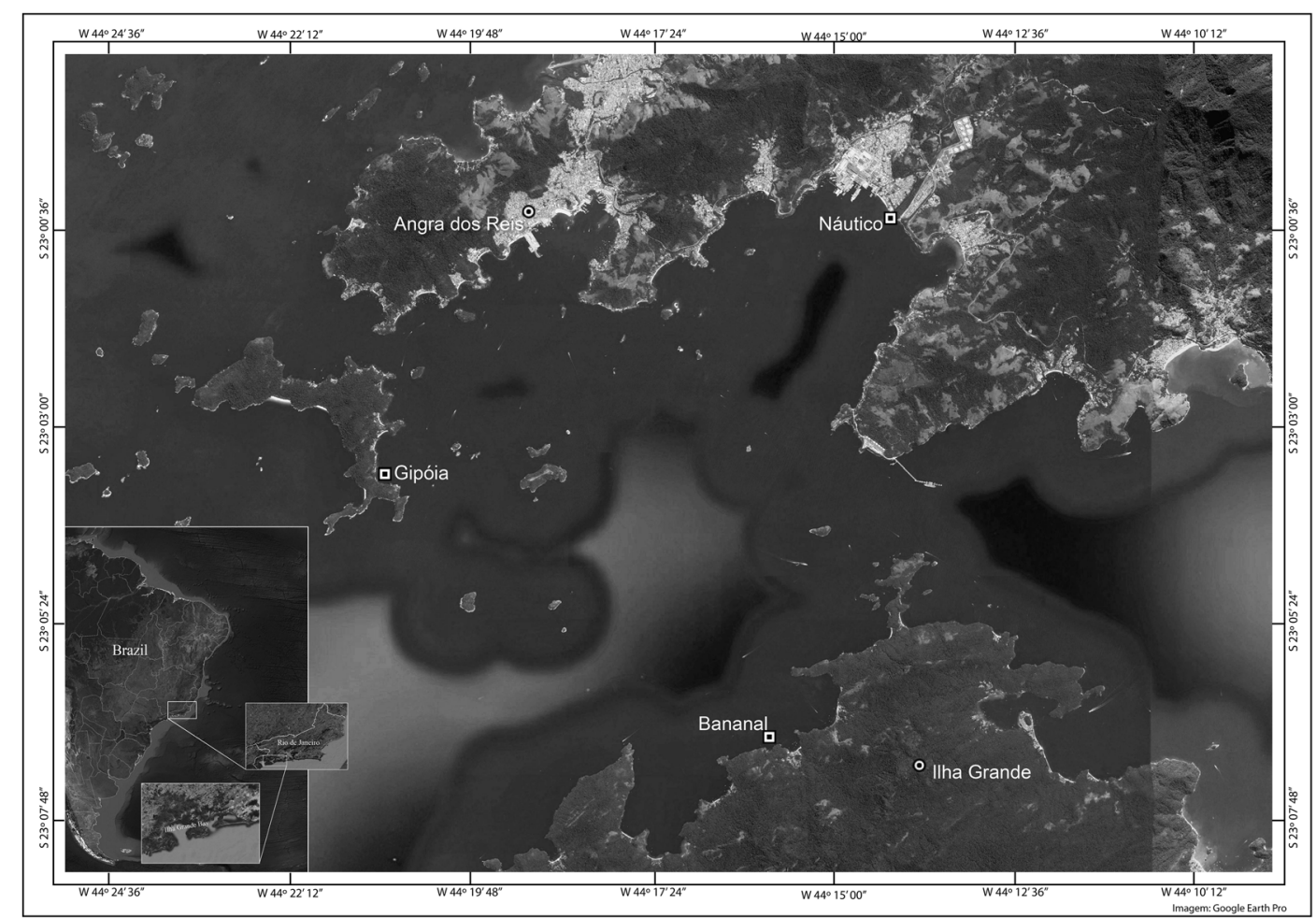

Fig. 1 Study site in Ilha Grande Bay, Angra dos Reis, RJ, Brazil. Sampling locations: Náutico (S 23 00' 29"; WO 44 14' 13"), Gipóia (S

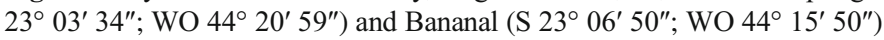

substances of interest through retention by a binding agent (typically a resin) immobilized in a gel. Before binding the resin, solutes pass through a diffusive membrane, with a thickness of $\Delta g$. According to the principles of the technique, the analyte concentration in the solution can essentially be determined by the equations below:

$M=C_{e}\left(V_{e}+V_{r}\right) / f_{e}$

$C_{b}=M \Delta g / D t A$

where $M$ is the recovered mass, $C_{e}$ is the ion concentration in the eluent, $V_{e}$ is the volume of acid used during elution, $V_{r}$ is the resin volume, $f_{e}$ is the mass fraction of metallic ions that can be removed by the acid during elution of the resins, $C_{b}$ is the free or labile concentration of metals in the outer solution, $\Delta g$ is the diffusive gel thickness, $D$ is the diffusion coefficient of metals, $t$ is the deployment time and $A$ is the exposure window area (Davison and Zhang 1994; Zhang and Davison 1995).
Device Assembly The DGT devices were assembled as previously reported (Tonello et al. 2011) using conventional binding gel (Chelex-100), polyacrylamideagarose diffusive gel (open pore) and cellulose acetate filter $(0.45-\mu \mathrm{m}$ porosity). All devices were identified with a number and a plastic bracelet circumventing the piston. To evaluate the possible presence of complexed metals (organic forms) and, consequently, variations in the diffusion coefficient of the species, DGT devices with lower porosity in diffusive gel layer were also assembled, described at this work as restrictive gels (Zhang et al. 2000; Zhang and Davison 2001). Additionally, to evaluate the influence of stirring and biofilm formation, DGT samplers with different diffusive membrane thicknesses $(0.8$ and $1.6 \mathrm{~mm})$ in the diffusive gel layer were assembled and used simultaneously (Zhang and Davison 1995).

Device Deployment The DGT devices remained immersed with the bivalves in cages commonly used in shellfish farming, confected with polypropylene plates and 15-mm-mesh-diameter silk cable. To avoid filter and membrane damage, the devices were housed in 
separate compartments from the bivalves. The DGT samplers were attached to the cages using 0.75-mmthick nylon lines. Number, type, deployment time and deployment sampling site of DGT devices in summer and winter campaigns are described in Table 1.

After the immersion period, the devices were removed from the cages, washed with ultrapure water and placed in locked and moistened plastic bags for transport to the laboratory.

\subsubsection{Bivalves: Transplantation and Deployment}

Individuals of $N$. nodosus (Linnaeus, 1758) species used in this study were obtained from the breeding farm of Pomar Project, belonging to the Institute for EcoDevelopment of Ilha Grande Bay, in Angra dos Reis, RJ. A total of 270 individuals were used in the winter and summer campaigns. The initial size of the animals was homogeneous, with a 4 to $5-\mathrm{cm}$ shell length. At this size, the animals are in their juvenile phase with reproductive organs that are not completely developed. This ensures that any change in bioaccumulation pattern caused by sexual differences had no influence on the study. The scallops were immersed at the study sites together with the DGT devices, lodged in appropriated cages. Conditional index (CI) was calculated for each sampling site and deployment times during the campaigns to evaluate the bivalves' physiological state during the experiment. The $\mathrm{CI}$ is the ratio between the dry weight $(\mathrm{g})$ of the soft tissue and the shell length (mm). It can be affected by intrinsic and extrinsic factor, such as gametogenic cycle, salinity, resources available and water temperature, and it has been used to reduce the variance between the data (Schintu et al. 2008).

At each removal time point (15, 30 and 60 days) in the two campaigns, 15 individuals were collected from each sampling site. A control sample with the same number of organisms was made for each campaign, and it was called in this work as reference animals (Table 2). After collection, the scallops died by freezing, and the entire soft contents of the animal were then transferred to $50-\mathrm{mL}$ Falcon tubes using plastic tweezers. The tissues of three animals were mixed in each tube, resulting in five combined samples from each sampling site (Bananal, Náutico and Gipóia) for each deployment time $(15,30$ or 60 days) in each campaign
Table 1 DGT device deployment

\begin{tabular}{|c|c|c|c|c|c|}
\hline \multirow[t]{2}{*}{ Campaign } & \multirow{2}{*}{$\begin{array}{l}\text { Sampling } \\
\text { site }\end{array}$} & \multirow{2}{*}{$\begin{array}{l}\text { Deployment } \\
\text { (days) }\end{array}$} & \multicolumn{3}{|c|}{ Number of DGT devices } \\
\hline & & & $\begin{array}{l}\text { 0.8-mm-thick } \\
\text { diffusive gel } \\
\text { (open pore) }\end{array}$ & $\begin{array}{l}0.8 \text {-mm-thick } \\
\text { restrictive gel }\end{array}$ & $\begin{array}{l}\text { 1.6-mm-thick } \\
\text { diffusive gel } \\
\text { (open pore) }\end{array}$ \\
\hline \multirow[t]{9}{*}{ Winter } & \multirow[t]{3}{*}{ Bananal } & 15 & 3 & 3 & - \\
\hline & & 30 & 3 & - & - \\
\hline & & 60 & 3 & - & - \\
\hline & \multirow[t]{3}{*}{ Gipóia } & 15 & 3 & 3 & 3 \\
\hline & & 30 & 3 & - & 3 \\
\hline & & 60 & 3 & - & 3 \\
\hline & \multirow[t]{3}{*}{ Náutico } & 15 & 3 & 3 & 3 \\
\hline & & 30 & 3 & - & 3 \\
\hline & & 60 & 3 & - & 3 \\
\hline \multirow[t]{9}{*}{ Summer } & \multirow[t]{3}{*}{ Bananal } & 15 & 3 & - & - \\
\hline & & 30 & 3 & 3 & - \\
\hline & & 60 & 3 & - & - \\
\hline & \multirow[t]{3}{*}{ Gipóia } & 15 & 3 & - & 3 \\
\hline & & 30 & 3 & 3 & 3 \\
\hline & & 60 & 3 & - & 3 \\
\hline & \multirow[t]{3}{*}{ Náutico } & 15 & 3 & - & 3 \\
\hline & & 30 & 3 & 3 & 3 \\
\hline & & 60 & 3 & - & 3 \\
\hline
\end{tabular}


Table 2 Bivalve (Nodipecten nodosus) deployment

\begin{tabular}{|c|c|c|c|}
\hline Campaign & $\begin{array}{l}\text { Sampling } \\
\text { site }\end{array}$ & $\begin{array}{l}\text { Deployment } \\
\text { (days) }\end{array}$ & $\begin{array}{l}\text { Number } \\
\text { of } \\
\text { bivalves }\end{array}$ \\
\hline \multirow[t]{10}{*}{ Winter } & Reference & 0 & 15 \\
\hline & \multirow[t]{3}{*}{ Bananal } & 15 & 15 \\
\hline & & 30 & 15 \\
\hline & & 60 & 15 \\
\hline & \multirow[t]{3}{*}{ Gipóia } & 15 & 15 \\
\hline & & 30 & 15 \\
\hline & & 60 & 15 \\
\hline & \multirow[t]{3}{*}{ Náutico } & 15 & 15 \\
\hline & & 30 & 15 \\
\hline & & 60 & 15 \\
\hline \multirow[t]{10}{*}{ Summer } & Reference & 0 & 15 \\
\hline & \multirow[t]{3}{*}{ Bananal } & 15 & 15 \\
\hline & & 30 & 15 \\
\hline & & 60 & 15 \\
\hline & \multirow[t]{3}{*}{ Gipóia } & 15 & 15 \\
\hline & & 30 & 15 \\
\hline & & 60 & 15 \\
\hline & \multirow[t]{3}{*}{ Náutico } & 15 & 15 \\
\hline & & 30 & 15 \\
\hline & & 60 & 15 \\
\hline
\end{tabular}

(winter or summer). Tissues were frozen and forwarded to the laboratory.

\subsection{Chemical Analysis}

\subsubsection{Equipments, Reagents and Accessories}

Equipments The equipments used in this study consisted of the following: orbital shaker (Labnet International, S2030-300-B-230 model, USA), lyophilizer (Thermo Fisher, FR-Drying Digital Unit Modulyod115 model coupled to Savant VLP120 vacuum bomb), microwave oven (Berghof, SW-4 model, Germany), sub-boiling acid distiller (Berghof, BSB-939-IR model, Germany), inductively coupled plasma-mass spectrometer with collision-reaction cell (ICP-MS, Thermo Scientific, X Series II model, Germany), inductively coupled plasma-optic emission spectrometer with dual view (ICP OES, iCAP, 6000 Series ICP Spectrometer, Thermo Scientific, Germany) and routine analytical chemistry laboratory equipments.
Reagents and Accessories The reagents and accessories used in this study were as follows: nitric acid $65 \%(\mathrm{~m} / \mathrm{m})$ (Merck, Darmstadt, Germany), hydrogen peroxide 30\% $(\mathrm{m} / \mathrm{m})$ (Merck), Chelex-100® resin 200-400 mesh (BioRad, Hercules, USA), DGT devices (DGT Research Ltd., Lancaster, UK), polyacrylamide-agarose binding gels entrenched with Chelex-100® resin (DGT Research Ltd.), polyacrylamide-agarose diffusive and restrictive gels (DGT Research Ltd.), 0.45- $\mu$ m cellulose acetate filtering membranes (Sartorius Stedim, Goettingen, Germany), glassware, plastic flasks and routine analytical chemistry laboratory accessories.

All glassware, plastic flasks, materials, filters, syringes and other accessories used during the entire collection and sample analysis process were previously decontaminated with $\mathrm{HNO}_{3} 20 \%(v / v)$. All solutions, dilutions and washes were performed using ultrapure water obtained from a MilliQ system $(18.2 \mathrm{M} \Omega \mathrm{cm}$ resistivity).

\subsubsection{Metal Analysis: DGT and Bivalves}

$D G T$ In the laboratory, the DGTs were dissembled, discarding the filters and diffusive gels, and the binding gels containing the resin were placed in $15-\mathrm{mL}$ Falcon tubes. Metals were eluted with $2 \mathrm{~mL}$ of sub-boiling distilled $\mathrm{HNO}_{3}$ at $1 \mathrm{~mol} \mathrm{~L}^{-1}$, and the samples were then stirred in an orbital shaker for $24 \mathrm{~h}$. Afterwards, the resins were removed from the tubes (de Souza et al. 2014).

The eluent was brought to $4 \mathrm{~mL}$ with ultrapure water, and metal concentrations were determined by ICP-MS. The operational conditions of the ICP-MS were as follows: $2.5 \mathrm{~mL} \mathrm{~min}^{-1}$ (V-groove nebulizer), $1450 \mathrm{~W}$ (plasma power), $0.92 \mathrm{~L} \mathrm{~min}^{-1}$ (nebulizer gas flow), $13 \mathrm{~L} \mathrm{~min}^{-1}$ (plasma gas flow) and $0.62 \mathrm{~L} \mathrm{~min}^{-1}$ (auxiliary gas flow).

Analytical curves were built from multi-element standard solutions (Specsol, São Paulo, Brazil) with the same acid concentration as the samples. For both standard solutions and samples, internal standards $\left({ }^{6} \mathrm{Li}\right.$, ${ }^{45} \mathrm{Sc},{ }^{89} \mathrm{Y},{ }^{165} \mathrm{Ho},{ }^{115} \mathrm{In},{ }^{159} \mathrm{~Tb},{ }^{209} \mathrm{Bi}$ ) were added at a concentration of $10 \mu \mathrm{g} \mathrm{L}^{-1}$.

Quantification limits (LOQs) of the DGT technique were calculated from control samples that were treated similarly to the deployed DGTs in terms of assembly, transport to the immersion site, elution and analysis. The LOQ for each deployment time was calculated by applying the mass retained at the control samplers in the 
subsequent DGT equations. Control tests of the quality of the DGT measurements were similar to those described previously (de Souza et al. 2014). The limits of quantification $(\mathrm{LOQ}=10 \sigma)$ obtained from direct analysis by ICP-MS for $\mathrm{Cd}, \mathrm{Co}, \mathrm{Cu}, \mathrm{Mn}, \mathrm{Ni}$ and $\mathrm{Pb}$ were $0.013,0.019,0.09,0.28,0.82$ and $0.05 \mu \mathrm{g} \mathrm{L}^{-1}$, respectively. The LOQs of the DGT diffusive (open pore 0.8$\mathrm{mm}$ thickness) technique are shown in Table 3.

Bivalves To determine the concentrations of metals, the flesh of scallops was macerated and prehomogenized until a mass with homogenous coloration and texture was obtained. Next, samples were frozen at $-80{ }^{\circ} \mathrm{C}$ and then lyophilized at approximately $-50{ }^{\circ} \mathrm{C}$ and from $30 \mu$ bar to 50 mbar for 4 days.

After lyophilization, the biological material was acid digested with heating in a microwave oven. Digestion procedures were adapted from the application report of the Berghof microwave (SW-4: MWS-2 Microwave Digestion of Fishmeal) and consisted of using $0.25 \mathrm{~g}$ of sample, $4 \mathrm{~mL}$ of sub-boiling $\mathrm{HNO}_{3} 65 \%(\mathrm{~m} / \mathrm{m})$ and $1 \mathrm{~mL}$ of $\mathrm{H}_{2} \mathrm{O}_{2} 30 \%(\mathrm{~m} / \mathrm{m})$ and heating to $220{ }^{\circ} \mathrm{C}$.

After digestion, solutions were brought to $25 \mathrm{~mL}$ with water, and the concentration of metals was determined by ICP-OES. The ICP-OES operational conditions were as follows: axial view, $3 \mathrm{~mL} \mathrm{~min}^{-1}$ (concentric nebulizer), $1150 \mathrm{~W}$ (incident power), $0.75 \mathrm{~L} \mathrm{~min}^{-1}$ (nebulizer gas flow) and $0.5 \mathrm{~L} \mathrm{~min}^{-1}$ (auxiliary gas flow). The LOQs $(10 \sigma)$ obtained by the transplanted bivalve technique for $\mathrm{Cd}, \mathrm{Co}, \mathrm{Cu}, \mathrm{Mn}, \mathrm{Ni}$ and $\mathrm{Pb}$ were $0.09,0.17,0.18,0.03,0.12$ and $0.73 \mu \mathrm{g} \mathrm{g}^{-1}$ (dry weight), respectively. The determination of all metals in the transplanted bivalves was possible in all exposure periods and sampling sites.

To validate the digestion method for the biological material analysed, analysis with certified reference materials (DORM-3: Fish Protein Certified Reference Material for Trace Metals and TORT-2: Lobster Hepatopancreas Reference Material for Trace Metals, both from National Research Council of Canada) and recuperation tests, adding $50 \mu \mathrm{g} \mathrm{L}^{-1}$ of the metals of interest to the scallop tissues, were performed. Recoveries from the certified reference material DORM-3 were $118 \%$ for $\mathrm{Cd}, 88.3 \%$ for $\mathrm{Cu}, 63.3 \%$ for $\mathrm{Mn}$ and $88.1 \%$ for $\mathrm{Ni}$. In the certified reference material TORT-2, the recoveries obtained were $87.5 \%$ for $\mathrm{Cd}, 88.5 \%$ for $\mathrm{Co}, 80.3 \%$ for $\mathrm{Cu}$, $82.4 \%$ for $\mathrm{Mn}, 75.8 \%$ for $\mathrm{Ni}$ and $104 \%$ for $\mathrm{Pb}$. In spiked scallop samples $\left(50 \mu \mathrm{g} \mathrm{L}^{-1}\right)$, the recoveries obtained were as follows: $98 \pm 0.02 \%$ for $\mathrm{Cd}, 92 \pm 2 \%$ for $\mathrm{Co}, 93 \pm 0.2 \%$ for $\mathrm{Cu}, 98 \pm 17 \%$ for $\mathrm{Mn}, 91 \pm 2 \%$ for $\mathrm{Ni}$ and $97 \pm 0.03 \%$ for $\mathrm{Pb}$. The procedures used for the extraction and determination of metals had satisfactory recoveries, although some variations occurred during analysis.

\subsection{Statistical Analysis}

Data were evaluated with respect to normality by a Shapiro-Wilk test. A non-parametric Wilcoxon-MannWhitney test was used to compare the different types and thicknesses of the gels in the DGT devices and to compare the results obtained from the winter and summer campaigns (for the DGT technique and transplanted bivalves). To compare the concentration of metals at the different deployment times and sampling sites, using both the DGT technique and the transplanted bivalves, a Kruskal-Wallis test, followed by Student-NewmanKeuls test, was performed. All analyses were performed using BioEstat 5.3 software, with $n$ equal to or greater than 5, considering a significance level of $\alpha=0.05$.

\section{Results and Discussion}

\subsection{DGT Technique}

Preconcentration capacity is one of the major advantages of DGTs, determining metals at trace and ultratrace levels. Preconcentration improves analyte quantification limits, as observed when comparing the LOQs of direct ICP-MS measurements with the LOQs of DGT coupled to ICP-MS (Table 3). An improved LOQ allows quantification of analytes that cannot be
Table 3 Limits of quantification $\left(10 \sigma, \mu \mathrm{g} \mathrm{L}^{-1}\right)$ of the DGT technique (coupled to ICP-MS) using different deployment times

\begin{tabular}{rlllllll}
\hline Gel & $\begin{array}{l}\text { Deployment } \\
\text { (days) }\end{array}$ & $\mathrm{Cd}$ & $\mathrm{Co}$ & $\mathrm{Cu}$ & $\mathrm{Mn}$ & $\mathrm{Ni}$ & $\mathrm{Pb}$ \\
\hline $\begin{array}{rlllll}\text { Diffusive_open } \\
\text { pore }(0.8 \mathrm{~mm})\end{array}$ & 15 & 0.0006 & 0.0004 & 0.16 & 0.016 & 0.017 & 0.05 \\
& 30 & 0.0003 & 0.0002 & 0.08 & 0.008 & 0.009 & 0.02 \\
& 60 & 0.0002 & 0.0001 & 0.04 & 0.004 & 0.004 & 0.01 \\
\hline
\end{tabular}


determined using conventional methods. The LOQ values determined for the DGT technique were similar to that reported by de Souza et al. (2014). These authors also discuss the impossibility of determining total and dissolved concentrations of metals in seawater samples by conventional methods due to the elevated LOQ (de Souza et al. 2014).

There were no differences in the results obtained with DGTs of different thicknesses and porosity. The absence of significant differences between diffusive and restrictive gels indicates that there was no expressive quantity of organic forms of the analysed metals in the seawater of IGB. Using gels with different porosities, de Souza et al. (2014) also found no presence of organometallic species in a region under petroliferous activities on the northeast Brazilian coast. Despite the biofilm formation, no significant differences were observed between the concentrations determined with different thickness gels in the diffusive layer for $\mathrm{Co}, \mathrm{Cu}$ and $\mathrm{Mn}$ at Naútico and for all metals at Bananal and Gipóia. Based on the obtained results, subsequent steps of the study were performed using only the data obtained from devices containing 0.8 -mm-thick diffusive gels (open pore).

\subsubsection{DGT Measurements}

Figures 2 and 3 present the concentrations of metals at IGB, RJ, obtained using the DGT technique. DGT devices with a 0.8 -mm-thick diffusive gel (open pore) were deployed for 15, 30 and 60 days at the three sampling sites during winter and summer campaigns.

All metals under study, except $\mathrm{Pb}$, were measurable by means of DGTs (Fig. 2). At the shortest deployment time (15 days) in the winter, $\mathrm{Pb}$ determination was only possible at Gipóia, while the concentration at the other stations was below the LOQ (see Table 3). In the winter campaign, $\mathrm{Mn}$ and $\mathrm{Co}$ concentrations were significantly different at 60 exposure days. This difference was caused by a concentration variation at the Náutico sampling site. In the summer campaign, significant differences were observed for $\mathrm{Cd}, \mathrm{Co}$ and $\mathrm{Ni}$. The Co concentration increased along the sampling periods, indicating a variation in the concentration of this element during the summer campaign that was similar to the behaviour of $\mathrm{Mn}$ in winter. Conversely, a significant decrease in the concentration of $\mathrm{Cd}$ and $\mathrm{Ni}$ was observed with time, suggesting a variation in the seawater concentration during the period. For $\mathrm{Cd}, \mathrm{Cu}$ and $\mathrm{Ni}$, differences in the concentrations between campaigns were not significant. However, for $\mathrm{Co}, \mathrm{Mn}$ and $\mathrm{Pb}$, the concentrations determined in the summer campaign were significantly higher than those in winter. Higher traffic from people and leisure vessels (touristic period) and more intense winds and rainfall (carrying contaminants) are possibly responsible for the higher levels of these metals in summer compared to winter. Furthermore, the availability of metals can be modified between campaigns due to seasonal variations in the physicochemical characteristics of the water.

The highest concentration of $\mathrm{Cd}$ obtained was $0.03 \mu \mathrm{g} \mathrm{L}^{-1}$, at Bananal. Other studies that used DGTs for $\mathrm{Cd}$ determination in uncontaminated areas found values from 0.005 to $0.15 \mu \mathrm{g} \mathrm{L}^{-1}$ (de Souza et al. 2014; Munksgaard and Parry 2003; Schintu et al. 2008, 2010; Webb and Keough 2002). The maximum $\mathrm{Cu}$ level detected in this study was $0.37 \mu \mathrm{g} \mathrm{L}^{-1}$, at Náutico. $\mathrm{Cu}$ concentrations from 0.01 to $1.92 \mu \mathrm{g} \mathrm{\textrm {L } ^ { - 1 }}$ have also been reported in seawater from uncontaminated areas using DGTs (de Souza et al. 2014; Munksgaard and Parry 2003; Schintu et al. 2008, 2010; Webb and Keough 2002). The levels of $\mathrm{Pb}$ found in this study (maximum of $0.08 \mu \mathrm{g} \mathrm{L}^{-1}$ ) are within the range of values found by previous studies deploying DGTs in uncontaminated areas, ranging from 0.01 to $0.86 \mu \mathrm{g} \mathrm{L}^{-1}$ (de Souza et al. 2014; Munksgaard and Parry 2003; Schintu et al. 2008, 2010; Webb and Keough 2002). The highest concentration of Co was $0.15 \mu \mathrm{g} \mathrm{L}^{-1}$ at Náutico, which is higher than that observed by Munksgaard and Parry (2003) in ocean waters around Australia in a previous similar work $\left(0.02 \mu \mathrm{g} \mathrm{L}^{-1}\right)$. The highest level of $\mathrm{Ni}$ in this study was $0.27 \mu \mathrm{g} \mathrm{L}^{-1}$, above that found in uncontaminated areas by Schintu et al. (2008) in a previous similar work carried out in Italy $\left(0.05 \mu \mathrm{g} \mathrm{L}^{-1}\right)$; this value is also higher than the concentration reported for a reference site for coastal areas in the Brazilian northeast $\left(0.02 \mu \mathrm{g} \mathrm{L}^{-1}\right)$ (de Souza et al. 2014). For Mn, no previous works reporting levels of the labile fraction of this element in ocean waters using DGTs were found.

\subsection{Transplanted Bivalve Technique}

Condition index for animals exposed in the winter during 15,30 and 60 days was $0.065 \pm 0.003,0.075 \pm 0.003$ and $0.089 \pm 0.004$, respectively. In the summer, CI was $0.073 \pm 0.005,0.088 \pm 0.006$ and $0.116 \pm 0.008$ for 15 , 30 and 60 exposure days, respectively. The CI for reference bivalves (exposure time $=0$ ) was $0.046 \pm 0.010$. CI for different sampling sites was not significantly 

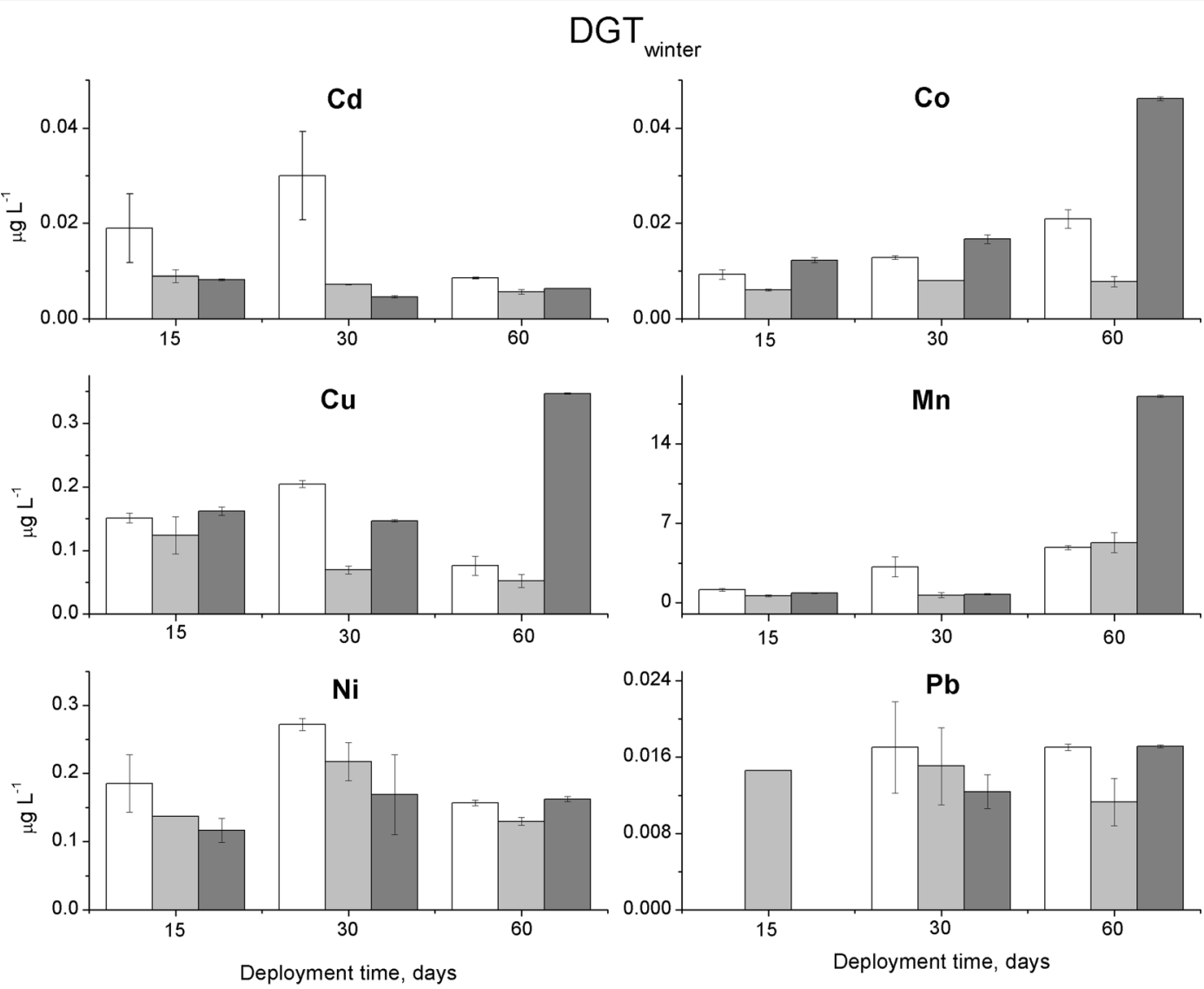

\section{Bananal $\square$ Gipoia $\square$ Nautico}

Fig. 2 Concentration of metals, mean $(n=3 \pm \mathrm{SD})$, determined by DGT devices with 0.8 -mm-thick diffusive gel and ICP-MS during winter at the three sampling sites in IGB (using LOD values)

different for both winter and summer. However, comparing deployment times, indexes for animals exposed for 60 days were higher than those for 15 days, showing $\mathrm{CI}$ increasing during the exposure period. In the summer, CI was significantly higher than those in the winter, probably because the shell growth at lower temperatures is typical for N. nodosus (Fonseca 2004).

\subsubsection{Metal Concentrations in the Tissues of Bivalves}

Figures 4 and 5 show the concentration of metals in the tissues of the transplanted bivalves ( $N$. nodosus) from IGB, RJ, determined by ICP-OES. In winter, the accumulation pattern of metals was characterized by a low concentration (except for $\mathrm{Cd}$ and $\mathrm{Pb}$ ) in the tissues of the reference animals that increased significantly when the animals were implanted at the sampling sites (15 and 30 days of deployment). Tissues of the analysed animals after 15 and 30 days were not significantly different in their concentrations of metals, being the higher concentrations observed in these periods. There was also a significant decrease in the levels of metals in the scallops by the end of the experiment, which was 60 days, compared to 15 and 30 days. These decreases were so marked for $\mathrm{Co}, \mathrm{Cu}$ and $\mathrm{Ni}$ that the animals exposed for the longest amount of time had concentrations similar to that observed in the reference animals. Perhaps, this pattern was observed because of the animal growth during the experiment (Schintu et al. 2008). Thus, for the same metal concentration in tissues, the animal weight was higher, which resulted in lower metal concentration per gramme of dry weight.

During the summer campaign, the observed pattern was characterized by relatively low concentrations in the reference animals, except for $\mathrm{Cd}$ due to the previous exposure discussed earlier. Animals with 15 days of 

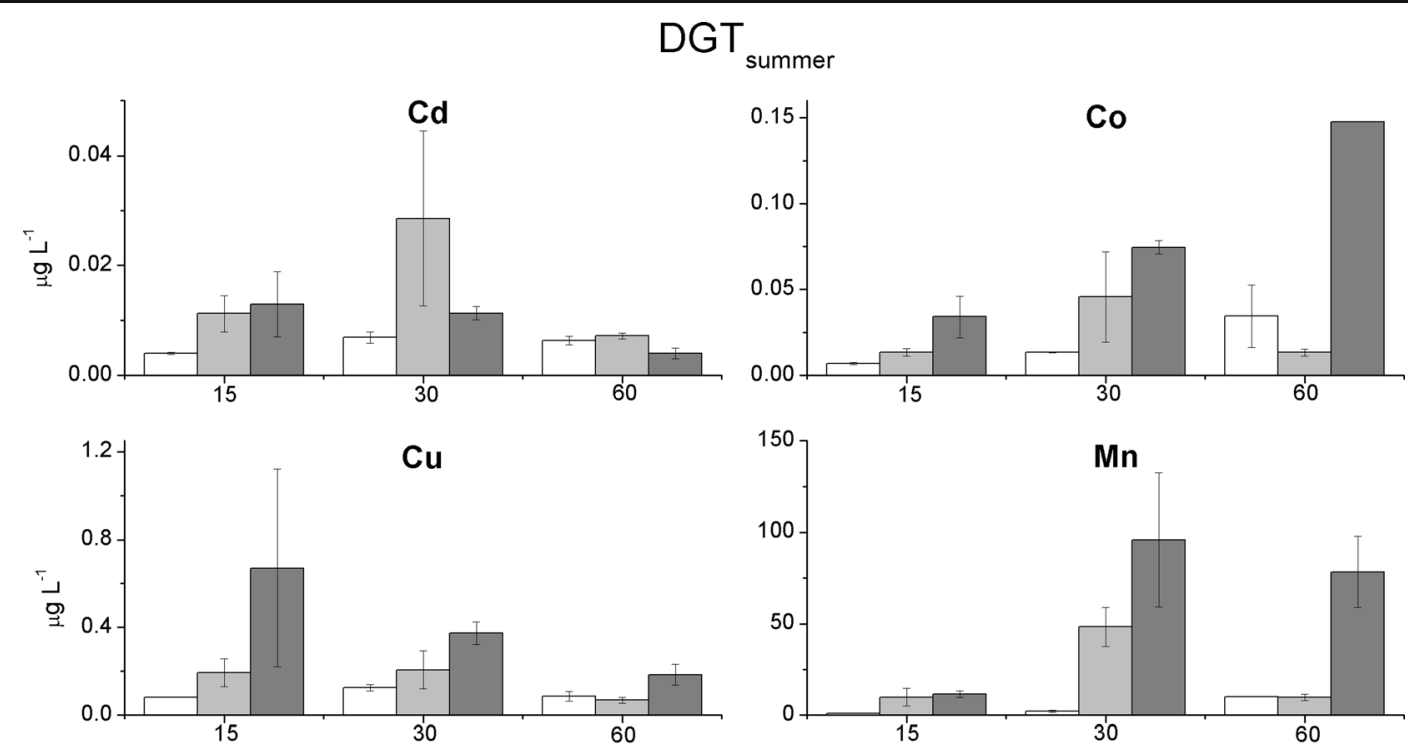

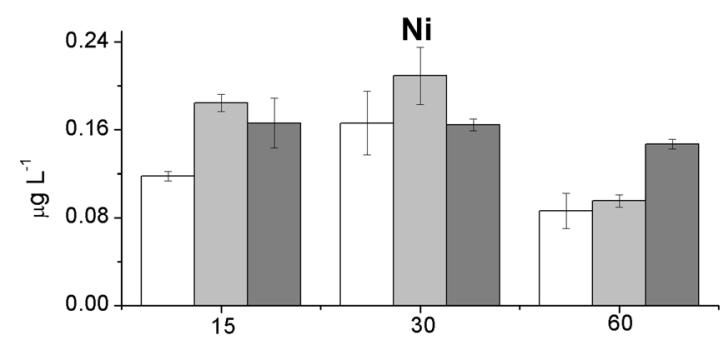

Deployment time, days

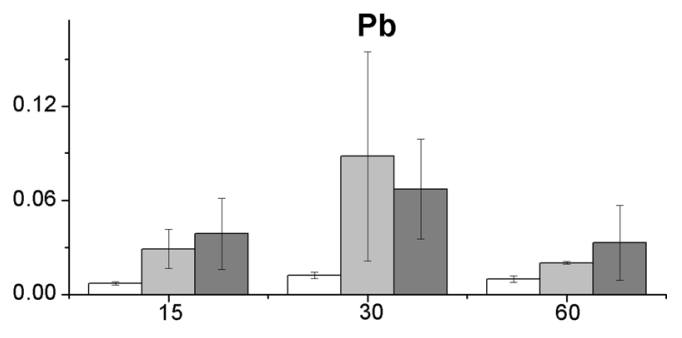

Deployment time, days

\section{Bananal $\square$ Gipoia $\square$ Nautico}

Fig. 3 Concentration of metals, mean $(n=3 \pm \mathrm{SD})$, determined by DGT devices with 0.8 -mm-thick diffusive gel and ICP-MS during summer at the three sampling sites in IGB (using LOD values)

exposure had tissue concentrations that were statistically equal to the references in most cases. With 30 days of exposure, Co levels were higher than in the references. $\mathrm{Co}$ and $\mathrm{Mn}$ also exhibited significantly higher concentrations at 30 days, compared to 15 days of exposure. For 60 days of exposure, Co values in the tissues of the bivalves were significantly higher than the reference values and at 15 days of exposure. Between 30 and 60 days of exposure, there were no significant differences for any of the metals. $\mathrm{Pb}$ and $\mathrm{Ni}$ exhibited no significant differences in the concentrations of the different exposure periods.

No significant differences were observed between the concentrations of metals determined in the tissues of the transplanted bivalves in the winter and summer campaigns. High $\mathrm{Cd}$ concentration has been previously measured in bivalves collected in the same farm (Francioni et al. 2004; Galvão et al. 2010) and because of this pre-exposure, the data for Cd were not compared with other studies/areas.

The highest concentration for Co $\left(0.93 \mu \mathrm{g} \mathrm{g}^{-1}\right)$ was detected at Náutico site, but it was lower than what has been reported in the literature for bivalves, from 1.7 to $31 \mathrm{\mu g} \mathrm{g}^{-1}$ (Bustamante and Miramand 2005; Pereira et al. 2012; Schintu et al. 2008; Webb and Keough 2002). For $\mathrm{Cu}$, the highest value obtained in this study was $7.8 \mu \mathrm{g} \mathrm{g}^{-1}$ found at Náutico site as well. Bellotto et al. (2005) reported similar levels $\left(7 \mu \mathrm{g} \mathrm{g}^{-1}\right)$ in Perna perna clams in a control area on the Santa Catarina coast, Brazil, while Pereira et al. (2012) found slightly higher concentrations $\left(10 \mu \mathrm{g} \mathrm{g}^{-1}\right)$ in Limnoperna fortunei from Rio Grande do Sul, Brazil. Lemos and Vieira (2013) reported Mn concentrations of $3.4 \mu \mathrm{g} \mathrm{g}^{-1}$ in Mytella guyanensis clams from Todos os Santos Bay (Bahia, Brazil), while Pereira et al. (2012) reported levels of $236 \mu \mathrm{g} \mathrm{g}^{-1}$ in clams from south Brazil. In the 


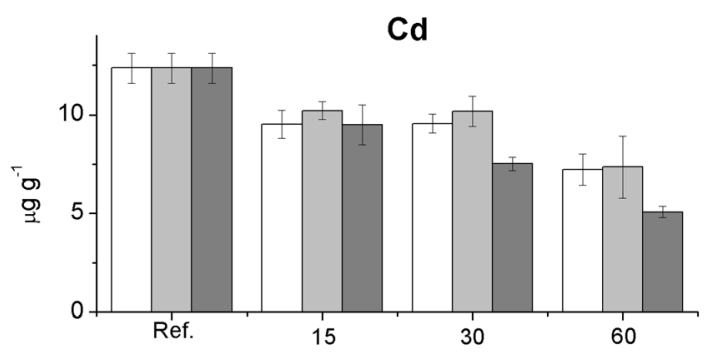

\section{Bivalves $_{\text {winter }}$}
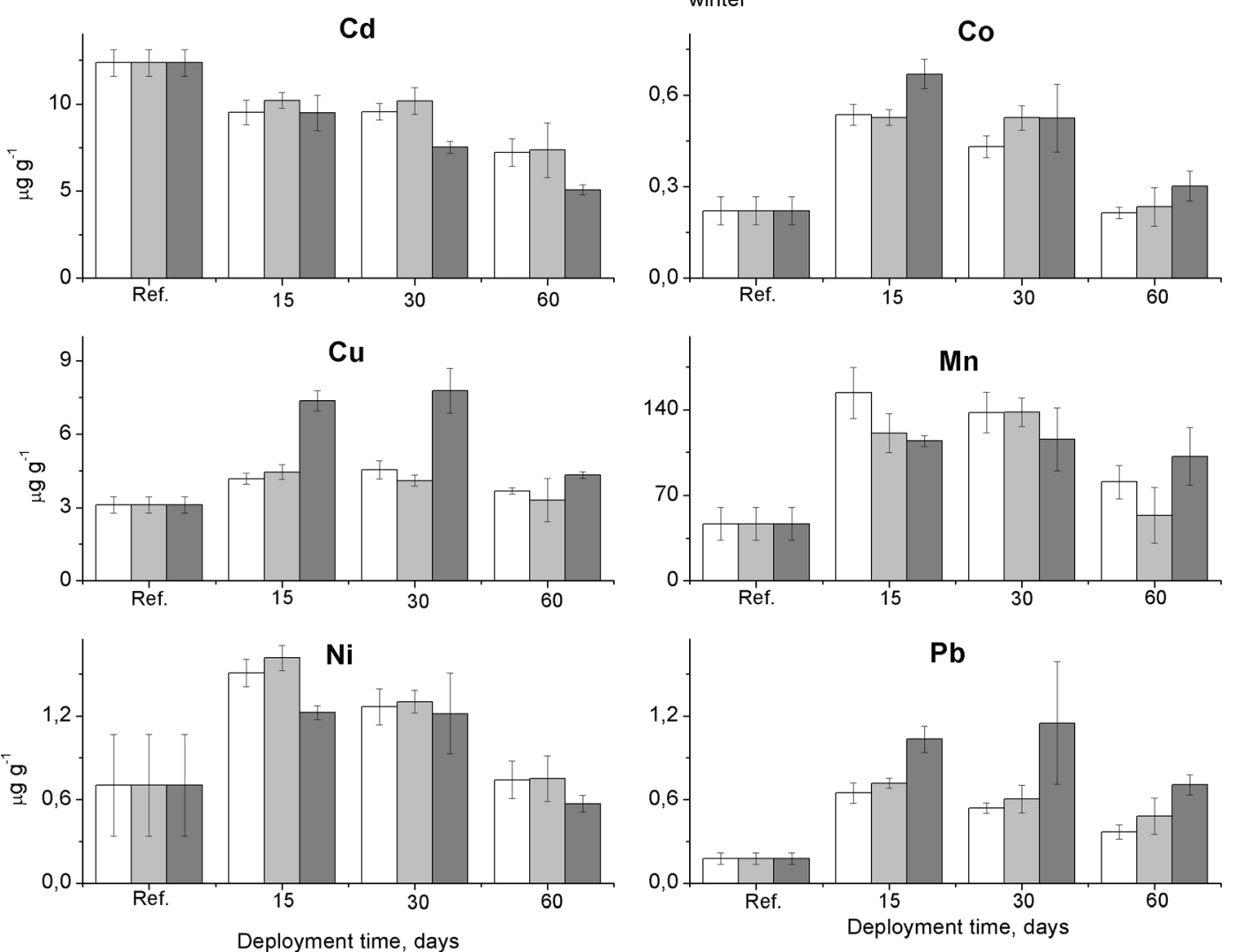

Bananal

Gipoia

Nautico

Fig. 4 Concentrations of metals, mean $(n=5 \pm \mathrm{SD}) \mu \mathrm{g} \mathrm{L} \mathrm{L}^{-1}$ dry weight, in the tissues of the transplanted bivalves during the winter campaign determined by ICP-OES for different exposure periods and sampling locations (using LOD values)

present study, the highest value detected for Mn was $200 \mu \mathrm{g} \mathrm{g}^{-1}$. The highest level of Ni determined in the present study was $1.5 \mu \mathrm{g} \mathrm{g}^{-1}$ at Gipoia; this value is below those reported in clams from seawater in uncontaminated areas: $8.5 \mu \mathrm{g} \mathrm{g}^{-1}$ for P. perna (Bellotto et al. 2005) and $7.5 \mu \mathrm{g} \mathrm{g}^{-1}$ for Mytilus galloprovincialis (Schintu et al. 2008). The maximum value for $\mathrm{Pb}$ in the tissues of the scallops was $1.3 \mu \mathrm{g} \mathrm{g}^{-1}$. This value is below $5.0 \mu \mathrm{g} \mathrm{g}^{-1}$ previously reported in M. galloprovincialis clams (Schintu et al. 2008; Webb and Keough 2002) and $6.6 \mu \mathrm{g} \mathrm{g}^{-1}$ in L. fortunei clams (Pereira et al. 2012). Metian et al. (2009) compiled a literature review on $\mathrm{Pb}$ levels in scallops of different species from different parts of the world, and these authors found varying concentrations from 0.6 to $16 \mu \mathrm{g} \mathrm{g}^{-1}$.

The transplanted $N$. nododus technique was efficient in distinguishing the variations in $\mathrm{Cd}, \mathrm{Co}, \mathrm{Cu}, \mathrm{Mn}$ and
$\mathrm{Pb}$ concentrations between the sampling sites. All the results that could be compared to the literature showed values similar to or below those previously reported, except for $\mathrm{Cd}$.

\subsection{DGT $\times$ Bivalves}

Based on the obtained concentrations and the statistical analysis performed, the sampling sites with the highest average concentration of metals (labile and bioavailable) in IGB were determined for the campaigns using DGTs and transplanted bivalves. Using the DGT technique, it was not possible to distinguish between the concentrations at the different sampling sites for $\mathrm{Mn}$ (winter) and $\mathrm{Ni}$ (summer). The data obtained were insufficient to perform the statistical tests on $\mathrm{Pb}$ during the winter campaign. The results obtained from the determination of 


\section{Bivalves}
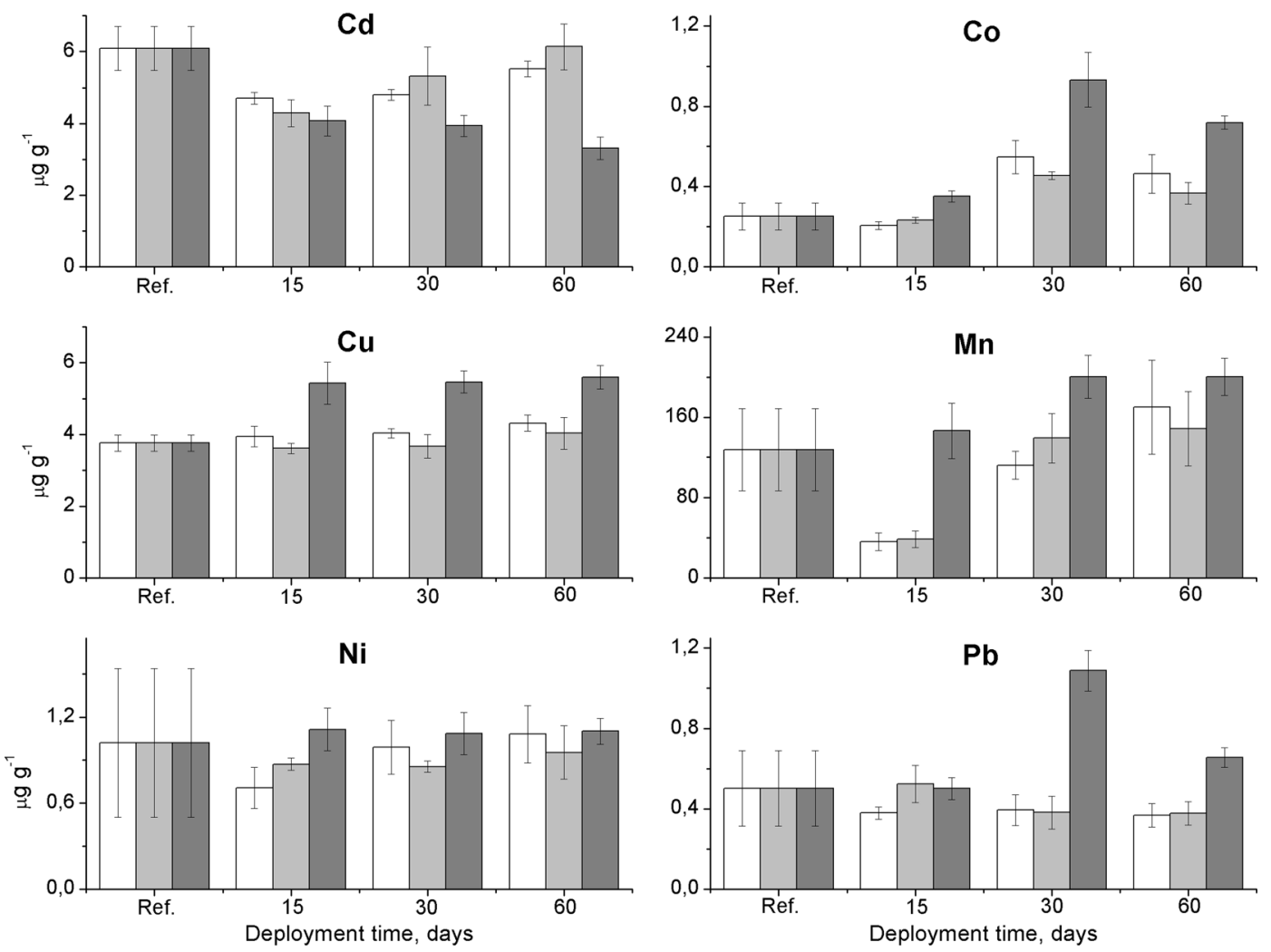

Bananal

\section{Gipoia $\square$ Nautico}

Fig. 5 Concentrations of metals, mean $(n=5 \pm \mathrm{SD}) \mu \mathrm{g} \mathrm{L}{ }^{-1}$ dry weight, in the tissues of the transplanted bivalves during the summer campaign determined by ICP-OES for different exposure periods and sampling locations (using LOD values)

metals in the tissues of the transplanted bivalves showed no significant differences between the locations for $\mathrm{Co}, \mathrm{Mn}$ and $\mathrm{Ni}$ in the winter campaign and for $\mathrm{Ni}$ in the summer campaign. The DGT technique measured higher concentrations of $\mathrm{Co}, \mathrm{Mn}$ and $\mathrm{Pb}$ in summer. However, these data were not consistent with that obtained in the bivalves. Labile concentrations determined by the DGT technique and concentrations in the bivalve tissues indicate that Náutico had the highest concentrations of metals of the sampling sites studied. Only for $\mathrm{Cd}$ the higher concentrations detected using DGT in both campaigns were not at Náutico. However, the data for bivalves were not conclusive due to the metal pre-exposure. As recent studies have reported for other areas (Bourgeault et al. 2013; Clarisse et al. 2012; Diviš et al. 2012; Ferreira et al. 2013; Mason et al. 2010; Schintu et al. 2008, 2010; Tusseau-Vuillemin et al.
2004; Webb and Keough 2002), the DGT technique provided data on the lability of metals in Ilha Grande Bay, which in most cases were correlated to the bioavailable fraction in organisms determined by the transplanted bivalve $N$. nodosus.

Náutico is the nearest location to the city of Angra dos Reis and has many sources of contamination in its surroundings, such as marinas, waste disposal sites, domestic sewage, intense vessel traffic and river discharge. These are possibly the causes of the higher levels of metals at this sampling location compared to the others. Unexpectedly, Bananal had several values above that obtained at Gipóia. A possible explanation for the concentration of metals at Bananal is an influx of contaminants via wind or ocean currents. Despite being far from any sources of contamination, Bananal is greatly affected by the winds that enter into the Bay. Gipóia is 
closer to the city of Angra dos Reis than Bananal and, for this reason, could have higher metal concentrations due to the same contamination sources as those at Náutico. However, in some cases, Gipóia exhibited lower levels of metals than the other sampling locations. Such results could be associated with the fact that there are few local contamination sources close to Gipóia and the islands of mountains surrounding this location can act as a barrier against wind and sea currents potentially carrying contaminants. For the first time, the labile concentrations and bioavailability of $\mathrm{Cd}, \mathrm{Co}, \mathrm{Cu}, \mathrm{Mn}, \mathrm{Ni}$ and $\mathrm{Pb}$ were described in IGB. Although this area can receive considerable amounts of contaminants, the results found in this work can be used as reference values for monitoring the area.

\section{Conclusions}

The method based on DGTs was successful in determining the concentration of the labile fraction of metals in IGB, RJ. No significant amount of organic metal species was detected. In most cases, the determination using the technique was not significantly affected by biofilm formation over the evaluated deployment time periods. Co and $\mathrm{Ni}$ were present at higher levels compared to the literature.

It was possible to determine all metals in the tissues of bivalves ( $N$. nodosus), indicating the bioavailability of these elements in the study area. Pre-exposure to $\mathrm{Cd}$ was evident in the animals, hindering the data interpretation for this element. The levels of metals found in the tissues of transplanted bivalves in IGB were similar to or lower than previously reported concentrations in other studies.

Concentration of $\mathrm{Cd}, \mathrm{Co}, \mathrm{Cu}, \mathrm{Mn}, \mathrm{Ni}$ and $\mathrm{Pb}$ in water obtained by DGTs and bioaccumulated in the soft tissues of bivalves was described in IGB for the first time. DGTs provided data on the lability of metals that, in most cases, were correlated to the bioavailable concentration evaluated by the transplanted bivalves. Both techniques determined that Náutico had the highest concentration of metals in the study area.

Acknowledgements The authors thank São Paulo Research Foundation (FAPESP grant \#2011/16579-2 and \#2012/09140-7) and Brazilian National Council for Scientific and Technological Development $(\mathrm{CNPq})$ for financial support. We also thank the
Petrobras' Research Center (CENPES/RJ) for the assistance in field activities and sample preparation.

\section{References}

Amato, E. D., Simpson, S. L., Belzunce-Segarra, M. J., Jarolimek, C. V., \& Jolley, D. F. (2015). Metal fluxes from porewaters and labile sediment phases for predicting metal exposure and bioaccumulation in benthic invertebrates. Environmental Science and Technology, 49(24), 14204-14212. doi:10.1021/acs.est.5b03655.

Bellotto, V. R., De Brito, P. C., Manzoni, G., \& Wegner, E. (2005). Biomonitoramento ativo de metais traço e efeito biológico em mexilhões transplantados para área de influência de efluente de indústria de beneficiamento de aço - Fase I. Brazilian Journal of Aquatic Science and Technology, 9(2), 33. doi:10.14210/bjast.v9n2.p33-37.

Belo, W. C., Dias, G. T. M., \& Dias, S. (2002). O fundo marinho da baía da Ilha Grande, RJ: o relevo submarino e a sedimentação do canal central. Brazilian Journal of Geophysics, 20(1), 6-15.

Bourgeault, A., Ciffroy, P., Garnier, C., Cossu-Leguille, C., Masfaraud, J. F., Charlatchka, R., \& Garnier, J. M. (2013). Speciation and bioavailability of dissolved copper in different freshwaters: comparison of modelling, biological and chemical responses in aquatic mosses and gammarids. Science of the Total Environment, 452-453, 68-77. doi:10.1016/j. scitotenv.2013.01.097.

Bustamante, P., \& Miramand, P. (2005). Evaluation of the variegated scallop Chlamys varia as a biomonitor of temporal trends of $\mathrm{Cd}, \mathrm{Cu}$, and $\mathrm{Zn}$ in the field. Environmental Pollution, 138(1), 109-120. doi:10.1016/j.envpol.2005.02.014.

Clarisse, O., Lotufo, G. R., Hintelmann, H., \& Best, E. P. H. (2012). Biomonitoring and assessment of monomethylmercury exposure in aqueous systems using the DGT technique. Science of the Total Environment, 416, 449-454. doi:10.1016/j. scitotenv.2011.11.077.

Creed, J. C., Pires, D. O., \& Figueiredo, M. A. d. O. (2007). Biodiversidade marinha da baía da ilha grande. Brasília: MMA/SBF.

Davison, W., \& Zhang, H. (1994). In situ speciation measurements of trace components in natural waters usinf thin-film gels. Nature, 387, 546-548.

Diviš, P., Machát, P., Szkandera, R., \& Dočekalová, H. (2012). In situ measurement of bioavailable metal concentrations at the downstream on the Morava river using transplanted aquatic mosses and DGT technique. International Journal of Environmental Research, 6(1), 87-94.

Ferreira, D., Ciffroy, P., Tusseau-Vuillemin, M. H., Bourgeault, A., \& Garnier, J. M. (2013). DGT as surrogate of biomonitors for predicting the bioavailability of copper in freshwaters: an ex situ validation study. Chemosphere, 91(3), 241-247. doi:10.1016/j.chemosphere.2012.10.016.

Fonseca, M. L. (2004). Anatomia funcional de Nodipecten nodosus (Linnaeus, 1758) (Bivalvia: Pectinidae). Instituto de Biociências. São Paulo: Universidade de São Paulo.

Francioni, E., Wagener, A. d. L. R., Calixtoa, R. d. C., \& Bastos, G. C. (2004). Evaluation of Perna perna (Linné, 1758) as a 
tool to monitoring trace metals contamination in estuarine and coastal waters of Rio de Janeiro, Brazil. Journal of Brazilian Chemical Society, 15(1), 103-110.

Galvão, P., Rebelo, M. F., Guimarães, J. R. D., Torres, J. P. M., \& Malm, O. (2009). Bioacumulação de metais em moluscos bivalves: aspectos evolutivos e ecológicos a serem considerados para a biomonitoração de ambientes marinhos. Brazilian Journal of Aquatic Science and Technology, 13(2), 59-66 file:///C:/Users/TaianaAraujo/Downloads/1359-41551-PB.pdf.

Galvão, P., Torres, J., Malm, O., \& Rebelo, M. (2010). Sudden cadmium increases in the digestive gland of scallop, Nodipecten nodosus L., farmed in the tropics. Bulletin of Environmental Contamination and Toxicology, 85(5), 463466. doi:10.1007/s00128-010-0120-z.

Lemos, V. A., \& Vieira, U. S. (2013). Single-drop microextraction for the determination of manganese in seafood and water samples. Microchimica Acta, 180(5-6), 501-507. doi:10.1007/s00604-013-0961-3.

Mason, S., McNeill, A., McLaughlin, M. J., \& Zhang, H. (2010). Prediction of wheat response to an application of phosphorus under field conditions using diffusive gradients in thin-films (DGT) and extraction methods. Plant and Soil, 337(1-2), 243-258. doi:10.1007/s11104-010-0521-0.

Metian, M., Warnau, M., Oberhänsli, F., \& Bustamante, P. (2009). Delineation of $\mathrm{Pb}$ contamination pathways in two Pectinidae: the variegated scallop Chlamys varia and the king scallop Pecten maximus. Science of the Total Environment, 407(11), 3503-3509. doi:10.1016/j.scitotenv.2009.02.010.

Munksgaard, N. C., \& Parry, D. L. (2003). Monitoring of labile metals in turbid coastal seawater using diffusive gradients in thin-films. Journal of environmental monitoring : JEM, 5(2), 145-149. doi:10.1039/b209346d.

Ohlander, B., Forsberg, J., Osterlund, H., Ingri, J., Ecke, F., \& Alakangas, L. (2012). Fractionation of trace metals in a contaminated fresh water stream using membrane filtration, ultrafiltration, DGT and transplanted aquatic moss. Geochemistry: Exploration, Environment, Analysis, 12(4), 303-312. doi:10.1144/geochem2012-125.

Pereira, É. R., Soares, B. M., Vieira, J. P., Mai, A. C. G., Picoloto, R. S., Muller, E. I., et al. (2012). Assessment of inorganic contaminants in golden mussel (Limnoperna fortunei) in southern Brazil. Journal of Brazilian Chemical Society, 23(5), 846-853.

Pinto, J. I. A. (2008). Estudo dos niveis de Hidrocarbonetos Policíclicos Aromáticos em Nodipecten nodosus (Coquilles Saint-Jacques) de Fazendas Marinhas da Bahia da Ilha Grande-RJ. Rio de Janeiro: Escola Nacional de Saúde Pública Sérgio Arouca/ FIOCRUZ.

Salomons, W., \& Forstner, U. (1984). Metals in the Hidrocycle (2a.). Berlin: Springer-Verlag.

Salomons, W., Forstner, U., \& Mader, P. (1995). Heavy metals problems and solutions. Berlin: Springer-Verlag.
Schintu, M., Durante, L., Maccioni, A., Meloni, P., Degetto, S., \& Contu, A. (2008). Measurement of environmental tracemetal levels in Mediterranean coastal areas with transplanted mussels and DGT techniques. Marine Pollution Bulletin, 57(6-12), 832-837. doi:10.1016/j.marpolbul.2008.02.038.

Schintu, M., Marras, B., Durante, L., Meloni, P., \& Contu, A. (2010). Macroalgae and DGT as indicators of available trace metals in marine coastal waters near a lead-zinc smelter. Environmental Monitoring and Assessment, 167(1-4), 653661. doi:10.1007/s10661-009-1081-8.

de Souza, J. M., Menegário, A. A., de Araújo Júnior, M. A. G., \& Francioni, E. (2014). Measurements of labile $\mathrm{Cd}, \mathrm{Cu}, \mathrm{Ni}, \mathrm{Pb}$, and $\mathrm{Zn}$ levels at a northeastern Brazilian coastal area under the influence of oil production with diffusive gradients in thin films technique (DGT). Science of the Total Environment, 500, 325-331. doi:10.1016/j.scitotenv.2014.08.117.

Stark, J. S., Johnstone, G. J., Palmer, A. S., Snape, I., Larner, B. L., \& Riddle, M. J. (2006). Monitoring the remediation of a near shore waste disposal site in Antarctica using the amphipod Paramoera walkeri and diffusive gradients in thin films (DGTs). Marine Pollution Bulletin, 52(12), 1595-1610. doi:10.1016/j.marpolbul.2006.05.020.

Tonello, P. S., Goveia, D., Rosa, A. H., Fraceto, L. F., \& Menegário, A. A. (2011). Determination of labile inorganic and organic species of $\mathrm{Al}$ and $\mathrm{Cu}$ in river waters using the diffusive gradients in thin films technique. Analytical and Bioanalytical Chemistry, 399(7), 2563-2570. doi:10.1007 /s00216-010-4603-x.

Tusseau-Vuillemin, M.-H., Gilbin, R., Bakkaus, E., \& Garric, J. (2004). Performance of diffusion gradient in thin films to evaluate the toxic fraction of copper to Daphnia magna. Environmental Toxicology and Chemistry, 23(9), 2154. doi:10.1897/03-202a.

Webb, J. A., \& Keough, M. J. (2002). Measurement of environmental trace-metal levels with transplanted mussels and diffusive gradients in thin films (DGT): a comparison of techniques. Marine Pollution Bulletin, 44(3), 222-229. doi:10.1016/S0025-326X(01)00244-2.

Zhang, H., \& Davison, W. (1995). Performance characteristics of diffusion gradients in thin films for the in situ measurement of trace metals in aqueous solution. Analytical Chemistry, 67(19), 3391-3400. doi:10.1021/ac00115a005.

Zhang, H., \& Davison, W. (2001). In situ speciation measurements. Using diffusive gradients in thin films (DGT) to determine inorganically and organically complexed metals. Pure and Applied Chemistry, 73(1), 9-15. doi:10.1351 /pac200173010009.

Zhang, H., Davison, W., Sciences, E., \& La, L. (2000). Direct in situ measurements of labile inorganic and organically bound metal species in synthetic solutions and natural waters using diffusive gradients in thin films. Analytical Chemistry, 72(18), 4447-4457. doi:10.1021/ac0004097. 